presents many problems of interest. The exploration of the potentialities of Derris as an insecticide is very encouraging, while proof that the alkaloid ephedrine, present in Indian species of Ephedra, is in no way inferior to the Chinese product as a potent remedy for asthma, opens up possibilities for India in this connexion. It is hoped that failure in the past to attend to certain essentials regarding the collection of the plants will be remedied and full advantage taken of the present opportunity for developing trade in Indian Ephedra. Among other subjects spike disease of sandalwood is still under investigation, but proof is needed that Jassidæ (leaf-hoppers) are the vectors concerned with the transmission of this baffling kind of disease.

\section{Scottish Society for Research in Plant Breeding}

THE report for 1940 of the director of the Plant Breeding Station at Craig's House, Edinburgh, includes several important practical results of scientific research. It is shown that the renovation of semiderelict pastures is best performed by ploughing up and re-sowing. A nurse crop of Sandy oats to be grazed in July, and a mixture of varieties of one grass species, together with wild white clover, are found to be preferable to sowing a mixture of grass species under rape or a seeding nurse crop of oats.

The Ainville sub-station, used for trials, has been transferred to six acres of land, six hundred feet above sea-level, at Boghall. The breeding of potatoes resistant to blight and to virus disease is meeting with considerable success, and several selections are being further tested. It is now possible to investigate the genetical background of resistance to pure strains of the $B, C$ and $X$ viruses. The available evidence indicates an autotetraploid segregation with dominance for susceptibility. Resistance to finger and toe disease in swedes is being tested both among new seedlings and in the field. Beans, wheat, barley and kale are among the other crops which are being bred for practical purposes under the guidance of scientific principles.

\section{Institute of Organic Chemistry in Moscow}

IT is announced by "Russia Today" Press Service that work has been commenced in Moscow on the new building for the Institute of Organic Chemistry of the Academy of Sciences of the U.S.S.R. The building will consist of three blocks, the main one of which (the laboratory block) will house the seven departments engaged in the study of the different branches of organic chemistry. This block will have a volume of $1,907,000$ cubic feet. In addition, there will be an autoclave building and a block for big installations and workshops, with an aggregate volume of 388,500 cubic feet. Spacious accommodation has been set aside for a library of 70,000 volumes, as well as a big reading-room and an auditorium for 250 persons. The cost of the new building, not counting special equipment, is estimated to be $12 \frac{1}{2}$ million roubles. It is hoped to complete it in 1942 .

\section{Military Training for University Students}

SINCE it is recognized that young men of eighteen and onwards at universities cannot undertake home defence duties without undue interference with their studies, it has been decided to expand the contingents of Training Corps at universities so that every student may enrol to obtain basic military training. Those who wish to serve in the Royal Air Force will have an opportunity of joining a university air squadron. By these means university education will be maintained, and undergraduates will be enabled to acquire useful experience.

\section{Postponement of Nobel Awards}

ON October 11 the Board of the Nobel Foundation asked the Swedish Government to allow a postponement in conferring the Nobel Prizes of 1940 for literature, physics, and chemistry until the 1941 prizes are conferred. The Medicine Prize was yesterday reserved until 1941 by the Faculty of the Carolean Medico-Surgical Institute in Stockholm.

\section{Announcements}

THE seventeenth award of the Duddell Medal of the Physical Society to Prof. E. O. Lawrence, of the University of California, which was announced in NATURE of June I, p. 852, has a significance deeper than the honouring of a great American physicist's achievements in the invention and development of the cyclotron. Circumstances permitting, Lord Lothian, the British Ambassador to Washington, will present the Medal to Prof. Lawrence at Philadelphia on the evening of December 27, 1940, the occasion being that of a dinner in connexion with a three-day meeting of the American Physical Society. It is a particularly appropriate occasion, for on the same day there is to be also a meeting of the American Association for the Advancement of Science, at which Prof. Lawrence, as a retiring vice-president, will address one of the sections.

The following appointments in the Colonial Service have recently been made: $P$. Adames, agricultural officer, Sierra Leone; E. S. Capstick, agricultural officer, Sierra Leone; J. H. Hinds, Agricultural officer, Gold Coast; J. A. N. Burra, assistant conservator of forests, Gold Coast; J. P. W. Logie, assistant conservator of forests, Kenya.

MoRE than 100,000 books were destroyed or severely damaged in a fire following the bombing of the University College library during a recent air raid on London. Two members of the staff were killed and eight were wounded, and the memorial hall was almost demolished.

Chronica Botanica, the international plant science journal, established in Holland in 1935, is being published fortnightly in the United States (annual subscription, about the same as formerly when the journal was published as a bi-monthly, 7.50 dollars, foreign and domestic, post paid). Communications should be sent to Dr. F. Verdoorn, P.O. Box 151, Waltham, Massachusetts. 